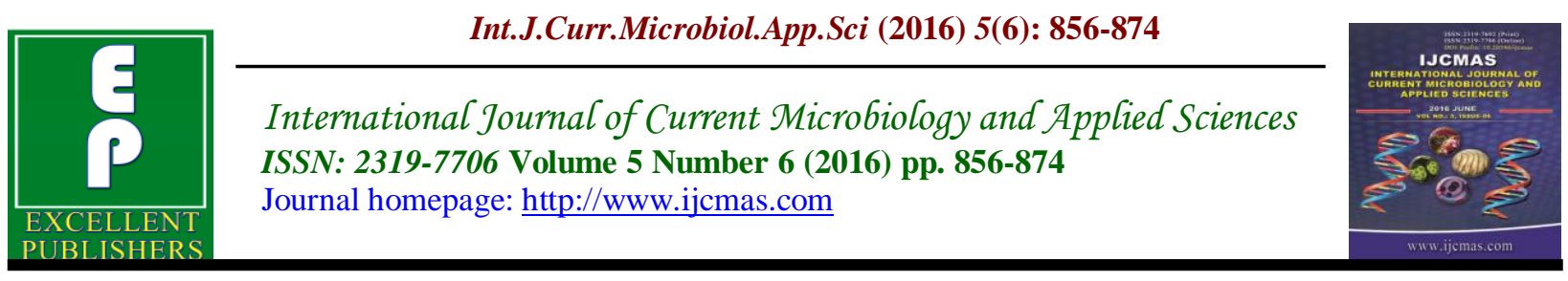

Original Research Article

http://dx.doi.org/10.20546/ijcmas.2016.506.093

\title{
The Use of Some Traditional Herbs to Activating the Immunity of Diabetic Rats
}

\author{
Magbolah, S.H. Al-Zahrany* \\ Biology Department, Faculty of Science, Al-baha University, KSA \\ *Corresponding author
}

\begin{abstract}
A B S T R A C T
Keywords

Immunity,

Liver enzymes, internal organs,

rats,

Diabetes mellitus, lipid profile

Article Info

Accepted:

28 May 2016

Available Online:

10 June 2016

The aim of this investigation is to evaluate the biological effect of herbs on lowering the level of glucose in blood and enhancement of the immune system. Thirty-two male albino rats $(130-200 \mathrm{~g})$ each were used in the study, 28 of rats diabetes by single intraperitoneal injection of alloxan at dose level of $150 \mathrm{mg} / \mathrm{kg}$ body weight. All rats (normal and diabetic) were kept on casein basal diet for 4 weeks. They were then divided into 5 groups. At the end of experiment the weight gain was calculated. Organs (liver-heart-kidney-spleen-lungs) of each rat were removed rapidly and were weighted separately. Blood samples were used for estimation of fasting serum glucose, serum GPT and GOT, serum lipid profile, kidney function, cellular and humoral immunity. Data showed that serum GOT and GPT levels declined significantly $(\mathrm{p}<0.01)$ in all treated groups that fed on $20 \%$ powder and extract when compared with diabetic control positive, while feeding rat on basal diet containing $20 \%$ herbs (2) extract, herbs (1) powder revealed more hypoglycemic effect. The best results for immunity were $20 \%$ herbs (3) powder, herbs (2) extract, herbs (2) powder group.
\end{abstract}

\section{Introduction}

Diabetes mellitus is a group of diseases characterized by a defect in insulin secretion and increased cellular resistance to insulin, resulting in elevated plasma glucose levels, abnormalities carbohydrate and lipid metabolism, characteristic pathologic changes in the nerves and small blood vessels, and aggravation of atherosclerosis (Lee and Nieman, 2003).

Since 1932, diabetes mellitus has been among the top 10 leading causes of death in America. It is a major cause of blindness, renal failure, congenital malformation, and lower extremity amputation. The prevalence of coronary artery disease and peripheral vascular disease is twice as common among persons with diabetes, as compared with those without diabetes (American Diabetes Association, 2014).

There are five categories of patients with diabetes, or impaired, glucose metabolism : Type 1 diabetes, type 2 diabetes, gestational diabetes mellitus, impaired fasting glucose, and impaired glucose tolerance. The vast majority of diabetes cases fall into two broad categories, type 1 diabetes and type 2 
diabetes (Lee and Nieman, 2003).In 1997, an estimated 124 million people worldwide had diabetes, $97 \%$ of these having type 2 diabetes, otherwise known as non- insulin dependent diabetes mellitus (NIDDM) or adult - onset diabetes - type 2 diabetes is most prevalent in the adult population, afflicting approximately $17 \%$ of people aged greater than 65 years (Winlers, 2006). The use of traditional plant for diabetes mellitus is widely practiced in Middle East countries. The world health organization (WHO) has recommended that this should be encouraged, especially in countries where access to the conventional treatment of diabetes is not adequate (WHO, 1980). Today we are witnessing a great deal of interest in the use of herbal remedies. Some consumers have become dissatisfied with conventional medicine. They perceive it as impersonal and expensive, and conventional drug therapy often has undesirable side effects.

For many Americans, the medicinal use of plant extracts seems to be a more natural, less expensive way, and involving therapies that are more gentle and largely without side effects (Watson, 2012). A number of herbal products are known to facilitate enhancement of the immune system. These include Echinacea, garlic, cat,s claw, astragolus, licorice and other herbs. Flavonoid- rich and carotenoid - rich herbs may be expected to enhance the immune system (Tyler, 1994).

\section{Material and Methods}

Studied ingredients were prepared prior to inclusion in diets as follows :

\section{Preparation of Plant Extracts}

The clean herbs were ground using porcelain grinder to pass through sieve mesh pores of $1 \mathrm{~mm}$ diameter and used as powdered dried plants.
Sample (400 g) of sample of herbs group $(1,2$ and 3$)+1000 \mathrm{ml}$ distilled water, were kept in conical flasks provided with glass condensers then boiled for one hour to obtain the extracts.

The boiled mixture was coded and filtered.

The filterate poured in different petri dishes and dried under vacuum at $70 \mathrm{o}$ c to dried powder. The powder has been dissolved in certain amount of distilled water. The amount of solution equivalent to $20 \%$ dried herbs was administered orally using a tube.

\section{Biological Investigation}

\section{Animals}

Thirty-two (32) Sprague - Dawley male albino rats weighting $130-200 \mathrm{~g}$ each, were used in this study. All rats were fed the control (casein) diet for 4 consecutive days. Each rat was housed in an individual stainless steel cage under controlled condition. Diets were introduced to rats in a special non- scattering feeding cups to avoid loss of food and contamination. Tap water was provided to rats by mean of glass tubes projecting through wire cages from inverted bottles supported to one side of the cage.

\section{Induction of Diabetes in Rats}

Alloxan: Pure chemical fine (BDH, obtained from Sigma) was used for inducing diabetes in this study.Untreated rats are referred to as the control negative (control-group), while alloxan treated rats are the control positive(control + group); these are groups 1 and 2 respectively. Diabetes was induced in normal healthy male albino rats via intraperitoneal injection of alloxan $150 \mathrm{mg} / \mathrm{kg}$ body weight according to the method described by Desai and Bhide, (1985). Six hours after the injection of 
alloxan, fasting blood samples were obtained by retro-orbital method to estimate fasting serum glucose. Rats having fasting serum glucose more than $200 \mathrm{mg} / \mathrm{dL}$ were considered diabetics NDDG, (1994).

\section{Diets}

Basal diet was prepared according to Reeves et al. (1993). It consists of $20 \%$ protein, 10 $\%$ sucrose, $4.7 \%$ corn oil, $2 \%$ choline chloride, $1 \%$ vitamin mixture, $3.5 \%$ salt mixture and $5 \%$ fibers. The remainder was corn starch up to $100 \%$.

\section{Experimental Diets}

Experimental diet was prepared from basal diet plus the powdered herbs group $(1, \mathrm{~A})$ (20\%), herbs extract (1,B) (20\%), powdered herbs group $(2, \mathrm{~A})(20 \%)$, herbs extract $(2, \mathrm{~B})(20 \%)$, and herbs group $(3, \mathrm{~A})$ $(20 \%)$, herbs extract $(3, \mathrm{~B})(20 \%)$.

\section{Experimental Design}

The experimental work was done in the Faculty of Science, AL-baha university. Rats were housed in wire cages in room maintained at $25 \pm 2$ o $\mathrm{C}$ and kept under normal healthy conditions. All were fed on normal basal diet for one week before starting the experiment for acclimatization. After one - week period, the rats were divided into groups each with similar alive body weight and were housed individually in wire cages.

\section{Rat Groups}

Group 1: Control group (control negative) 4 rats (normal rats) - in which rats were fed normal - basal diet for 28 days.

Group 2: Control positive group (control +) -4 rats. In which rats were fed normal - basal diet for 28 days. These rats were randomly chosen after injection with alloxan by six hours.

Group 3: (herbs group 1) (8 hyperglycemic rats) were fed on basal -diet containing herbs which were : El - saad (Lyprus rotondus), Reed (Arundo donax, L.)(boos), Rhubarb (Rheubarbarum officinale, L.), Mulberry leaves (Morus alba, L.), This group was furtherly subdivided into 2 subgroups :

Group 3 a: (Powdered herbs group 1) - 4 rats : In which rats were fed $20 \%$ powdered herbs diet for 28 consecutive days.

Group 3 b: (herbs 1 extract) - 4 rats : In which rats were fed normal -basal diet mixed with $20 \%$ herbs extract for 28 days.

Group 4: (herbs group 2) (8 hyperglycemic rats) were fed on basal - diet containing herbs which were : Rosmary (Rosmarinus officinalis L.), Angelica (Angelica archangelica, L.), Burdock (Arctium majus), Horehound (Marrubium vulgare, L.), This group was furtherly subdivided into 2 subgroups :

Group 4 a: (powdered herbs group 2) - 4 rats : In which rats were fed $20 \%$ powdered herbs diet for 28 consecutive days.

Group 4 b: (herbs 2 extract) - 4 rats : In which rats were fed normal -basal diet with $20 \%$ herbs extract for 28 consecutive days.

Group 5: (herbs group 3) (8 hyperglycemic rats) were fed on basal - diet containing herbs which were : Wormwood (Artemisia obsinthium L.), Barberry (Berberis vulgaris, L.), Fumitory (Fumoria officinalis, L.), Avens (Geum urbanum, L.), This group was furtherly subdivided into 2 subgroups : 
Group 5 a: (powdered group 3) - 4 rats : In which rats were fed $20 \%$ powdered herbs diet for 28 consecutive days.

Group 5 b: (herbs 3 extract) - 4 rats : In which rats were fed normal -basal diet with $20 \%$ herbs extract for 28 consecutive days.

\section{Blood Sampling}

From all the previously mentioned groups, blood samples were collected after 12 hour fasting at the end of the experiment. Using the retro - orbital method by means of a microcapillary glass heparinized tubes, blood was collected into a dry clean centrifuge tube and left to clot in a water bath (37c)at room temperature for half an hour. The blood was centerifuged for 10 minutes at 3000 r.p.m. to separate the serum.

Serum was carefully aspirated and transferred into clean quit fit plastic tubes and kept frozen at (20c) until the time of analysis. The organs (liver, kidney, heart, lungs and spleen)were removed and washed in saline solution, weighted and kept in formalin solution $(10 \%, \mathrm{v} / \mathrm{v})$ according to methods described by Drury and Wallington (1980), dried then weighted and relative weight of organs was calculated.

$$
\text { Relative weight }=\quad \frac{\text { Organ weight }}{\text { Animal body weight }} \times 100
$$

Biological Evaluation

All rats were weighted once weekly. At the end of the experiment, biological evaluation of the different diets was carried out by determination of body weight gain \% (BWG $\%$ ), food efficiency ratio (FER) according to Chapman et al., (1959). Using the following formulas.

\section{Biochemical Analysis}

Immunity Study: Assessment of both cellular and humoral immunity efficiency was carried out in the Faculty of Science AL-Baha University. Total serum proteins were determined by using biuret reaction according to Weichselbaum (1946).

Quantitative Estimation of Fractions of Serum Proteins: According to the technique described by Laemmli (1970).Cellular immune response : Separation of lymphocytes : (Boyum, 1968 and Burrels and Wells,(1977). Total lymphocyte count (Hudson and Hay, 1980).According to viability cel 1 count (Rai-El-Balahaa et al., 1985). (Denise et al., 1992) Phagocytosis according to :(Woldehiwet and Rowan, 1990).

Determination of Blood Glucose: carried out Tietz (1976) and Yound (1975). triglycerides was carried out according to Jacobs and Van Denmark (1960). HDL according to the method of Fnedewaid (1972) and Gordon and Amer (1977). Determination of VLDL and LDL carried out according to the method of Lee and Nieman, (1996).Determination of (GOT) was carried out according to the method of Henry (1974) and Yound (1975) Creatinine: concentration according to Larsen, (1972).Uric acid: was according to Carawy, (1955)Urea: was according to Fawcette and Scott (1960).

\section{Statistical Analysis}

Statistical analysis were performed by using computer program statistical package for social science (SPSS), and compared with each other using the suitable tests. All obtained results were tabulated. Statistical analysis has been achieved using IMB-P-C computer by SPSS, program (SPSS, 1998).

\section{Result and Discussion}

Food intake (FI), body weight gain (BWG) and food efficiency ratio (FER): Data of 
tables (1) show FI, BWG \% and FER of hyperglycemic rats as affected by feeding on f herbs (1), (2), \& (3) diet. It could be observed table (1) that due to hyperglycemia loss of weight occurred and negative value of BWG was recorded; BWG $\%$ for control (+) group was $12.73 \%$ this was not due to loss of appetite (FI increase /from (16.9 to 17.1 g/day), but was possibly due to physiological disorders causing lower food efficiency ratio which decreased from 0.055 to -0.400 and lower protein efficiency ratio which declined from 0.458 to -0.332 . Similar trends were reported by Ahmed, Reham (2010) which found that diabetic rats showed negative values of FER (-014) and BWG \% (-20.69 \%); food intake was decreased from 13.99 to $11.53 \mathrm{~g} /$ day. Also our findings agree with those of Stoev et al.,(2010), who found that statistically significant decrease of the body weight for control positive group and increased organs weight. Rats fed on herbs (table 1) showed no more negative values for FER, PER, or BWG \% indicating that all plant materials used corrected the mentioned changes; but to different levels.

Sometimes the improvement in (PER, FER, BWG \%) so pronounced that values were ever better than that of the control (-) group. This may be noticed for herbs (2) powder and herbs (3) powder, as follows: herb (2) powder, herb (3) powder, powder groups collection, followed by the collection including herb (1) extract, herb (4) extract, and herb (3) extract.. As for overall the botanical materials the nearly same arrangement was recorded for PER, FER and BWG \% showing three collections; best one composed of herb (2) powder, followed by herb (3) powder. Anyhow best diet (table 1) was that of $20 \%$ herbs (2) group as it showed higher PER, FER \& BWG \%. Data of tables (2) show the weight of internal organs of hyperglycemic rats as effected by feeding of herbs diets. It could be noted that due to hyperglycemic the weight of heart, kidneys and spleen increased, while that of liver and lungs decreased. These changes were corrected at different degrees when feeding on tested plant parts. This was found El-Sayed (2001) who found a significant increase in liver weight of rats fed diet containing $5 \% \quad P$. oleracear leaves, being possibly due to changes in liver content of liver. In diabetics, the enlargement of the kidney and increased number of glomeruli undergo hypertrophy occurred to compensate for the loss of filtration from the scarred glomeruli (Velasquez etal., 1995). The increase in kidney weight also was probably due to fatty in filtration as reported by Ahmed, Reham (2010). The decrease of spleen weight due to feeding on test plants.

\section{Biochemical Parameters}

\section{Serum Glucose}

Data presented in table (3) show the serum glucose level of hyperglycemic rats when feeding with 3 different groups of herbs for 28 days. It could be observed that none of the herbs groups reduced serum glucose to the level recorded for control (-) group, although much great reduction occurred. Herbs (2) extract showed $37.3 \%$ decrease compared to control(+) group, which indicates considerable reduction in the serum glucose. In case of herbs group (2) best results were obtained, where the extract $\&$ the powder showed $37.3 \& 36.6 \%$ decrease of serum glucose as compared to control (+) group. No statistical difference ( $\mathrm{p}<0.01$ ) was found between both groups, they revealed $93.6 \& 94.6 \mathrm{mg} / \mathrm{dl}$ of serum glucose, indicating $37 \%$ decrease compared to control (+). The present results are confirmed by the findings of Herrera et al., (2004) they found that Marrubium vulgare leaf have been widely used in Mexican traditional medicine for the control of type 2 diabetes. 
The present results are in good agreement with these obtained by Korkmaz and Gurdal (2002) they found aqueous extract Artemisia Santonicum, $L$. reduced blood glucose level significantly $(\mathrm{p}<0.01)$.

Also, our findings agreement with Lau et al., (2006) they found that Rheum Palmatum, L. inhibition of glucose transport in the small intestine and inhibition of glucose reabsorption in the kidney. For fibers groups (1, $2 \& 3)$, the hypoglycemic effect of the powder table (3) was much greater than of the extract for herbs group 2, similar effect was found for powder \& extract) and difference were statistically significant at 1 $\%(\mathrm{p}<0.01)$.

As mentioned before Badria and Ibrahim (2013), many factors may be involved as the level of crude fiber, soluble fiber, minerals (as chromium), phytochemicals, oligosaccharides, monounsaturated fatty acids (monoenoic FA) \& n-3 fatty acids and other components. The hypoglycemic effect of herbs group (2) come first, followed by that of herbs group (1).herbs (2) extract 93.6, 37.3, herbs (2) powder (94.6, 36.6); herbs (1) powder in diabetics, so that it is important, with the help of nutrition, to achieve optimal lipid levels for persons with diabetes $(A D A, 2014)$. Data presented in table (4) show the level of serum lipids fractions (TC, TG, HDL, LDL, vLDL) and calculated atherogenic index (AF) of hyperglycemic rats. It could be noticed (4) that along with the increase of serum glucose (Table 4) in diabetic rats, fasting serum TC, TG, LDL \& vLDL were increased, while the level of HDL decreased. This is a usual disorder recorded for hyperglycemia (Mohamed, Manal 2006). nevertheless, Moreover, El-Adawi (1997) found that the concentration of plasma cholesterol, triglycerides, fatty acids and phospholipids are increased in diabetes mellitus. Diabetic rats exhibited high triglycerides and phospholipids compared to normal rats. Insulin also affect fat metabolism. Lack of insulin causes extreme atherosclerosis, often leading to heart attack.

It causes also a great increase in the amount of stored triglycerides in the liver, leading to a very fatty liver. The reason is the following: the excess of free fatty acids in the blood causes a rapid diffusion of fatty acids into the liver cells (Lee and Niemen, 2003). It could be noticed (Table 4 ) that best treatment, which showed lowest TC, TG, LDL and highest HDL were the collection of herbs groups (Table4) discipline of the arrangement order was noticed only for LDL and A.I. values where best treatment was the herb (1) powder, followed by the collection of herbs (2, \& 3)extracts groups, finally came the collection of powdered herbs (1), (2) \& (3).

In case of herbs, the best results (based on LDL and AI levels) were found for herb (1) powder compared to the extract, while the extracts were better than the powders considering herbs (1), (2) \& (3).

Our findings agreement with Sauls et al., (2006) they found that red wines and grape decrease lipid profile and saturated fatty acids. Also, flavonoids are very effective antioxidants and they protect LDL cholesterol from oxidation as well as inhibiting platelet aggregation (Cook and Samman, 1996). These results were in agreement with Hussein,(2001) who found that adding germinated fenugreek decreased triglycerides significantly among diabetic rats. The results arrived at revealed that best treatment for the lipids profile of hyperglycemic rats was the herbs (1) powder which showed.

It could be noticed that all tested botanical materials decreased LDL and AI when compared with control (+) group. Moreover 
best treatment herb (1) powder decreased LDL \& AI levels even when compared with control (-) group. Also fruit extract and vegetable powder reduced AI compared to control (-) group, and extracts of herbs (2)and (3). These results were in agreement with Kim et al., (2015) they found that mulberry leaves decoction decreased cholesterol, triglyceride, LDL and vLDL. The reduction in the level of cholesterol may be due to the inhibitory effect of the studied dietary fiber on the pancreatic enzymes (Mahfouz, 1992).These results of the present work agreement with (Wang et al., 2006) they found that Artemisia sphaeroc ephala at dose of $200 \mathrm{mg} / \mathrm{kg}$ body weight produced significant decrease in blood glucose level, plasma cholesterol and triglycerides in both normal and diabetic group. Chen et al., (2005) they found that Rheum palmatum, $L$. reduced post prandial hypertriglyceridemia was highly correlated with the improvement in gastrointestinal transit. Khalil et al., (2006) they indicated that Marrubium vulgare extract inhibit LDL oxidation and enhance reverse cholesterol transport and prevent cardiovascular disease. Also, increased HDL. Herrera et al., (2004) they noticed that Marrubium vulgare leaf extract reduced glucose level by $0.64 \%$ and cholesterol and triglycerides by $4.16 \%$ and $5.78 \%$ respectively.

\section{Effect of herbs groups on the liver function of diabetic rats}

Data of table (5) show the activities of GPT (AST) and GOT (AST) enzymes as influenced by feeding on herb (1,2 \& 3) diets (powders and extracts). It is evident (Table 5) that the activities of GPT and GOT could be nearly arranged the same and ascendingly as follows:

Arrangement of herbal groups was different, being also nearly the same for GPT and GOT. With few exception the ascending arrangement was as follows: Herbs (3) powder, herbs (2) extract, herbs (1) extract, herbs (1) powder, herbs (2) powder, herbs (3) extract. Some diets (herbs (1) extract) decreased the GPT activity exactly to the level recorded for the control (-) rats (26 $\mathrm{u} / \mathrm{L})$.Some other diets reduced the GPT herbs (2) extract, herbs (3) powder which was less than that recorded for the control (-) group. Our findings agreement with Eidi et al., (2006)) they found that leaf (Brassica juncea) reduced serum glucose lipid peroxidation,liver and kidney associated with diabetes mellitus. Also, these results agreed with that of Ghamry, (2004). The present result agreed also with those that of Nada et al., (1997).

\section{Effect herbs diets groups on the kidneys function of diabetic rats}

Diabetic nephropathy is a major complication of both insulin - dependent and non insulin - dependent diabetes mellitus, as reported by Velasquez et al., (1995), they suggested that hyperglycemia in diabetes is a critical factor in the development of the renal disease. Non protein nitrogen of the blood includes urea, uric acid and creatinine. They are usually of greater clinical interest.

Hyperglycemia, thereby caused the disorder of kidneys function as indicated by the increase of serum creatinine, were and uric acid levels (Table 6). This confirmed the results obtained by others (El-Sayed, 2001, Mohamed, 2006 and Ahmed, 2010).. Vats et al., (2003) they found that Brassica juncea improvement in most of the parameters creatinine, urea and uric acid. All botanical material used in present study corrected the disorders of kidneys function to different degrees as compared with control (+) group. In case of urea, however, none of diet reduced the level than that recorded for 
control (-) rats. On the other hand the control (-) groups which were: Creatinine (herb (1) powder, herb (1) extract, Uric acid herbs (1) extract and herbs (3) powder. Botanical materials of table (6) all botanical groups was as follows: Creatinine; herbs (1) powder, herbs (2) powder, \& herbs (1) extract, herbs (3) powder, herbs (2) extract, herbs (3) extract,; Urea:, herbs (3) powder, herbs (2) powder, herbs (1) powder, herbs (2) extract, herbs (3) extract, herbs (1) extract, herbs (3) extract,; Uric acid, herbs (2) extract,, herbs (1) extract, herbs (3) powder, herbs (3) extract, herbs (1) powder, herbs (2) powder;

\section{Immunity Parameters}

\section{Cellular Immunity}

Data of tables (7) show that differences between all treatments were insignificant when cellular immunity based on phagocytes was considered. Regardless of statistical analysis, however, treatments could be arranged descendingly based on phagocytes analysis as follows: herb (3) powder, herb (3) extract, herb (2) powder, herb (2) extract, herb (1) extract, herb (1) powder. The diet showing least correction as compared to control positive group, revealed about $13 \%$ improvement, indicating its benefit. Cellular immunity based on lymphocytes was more pronunnced compared to that of phagocytes; differences were significant between control (-) and control (+) groups. Also, a significant differences were found between all treatments on one side, and the control (+) group on the other hand side.

Improvement due to consumption of herbs diet ranged between 42 and $111 \%$. This indicated that least effecting diet (herbs (3) powder) corrected the decline of immunity due to hyperglycemia at $42 \%(41.76 \%)$ level while may be considered a pronunnced improvement. Based on lymphocytes different diets could be arranged descendingly as follows: herb (2) extract, herb (2) powder, herb (1) powder, herb (3) extract, herb (1) extract, and herb (3) powder. Overall descending arrange of immunity for all botanicals tested in present work based on phagocytes may be as follows: Herb (3) powder, herb (3) extract, herbs (2) powder, herbs (2) powder, herbs (1) extract, herbs (1) powder. Based on lymphocytes, cellular immunity when feeding different diets could be arranged descendingly as follows: Herbs (2) extract, herbs (2) powder, herbs (1) powder, herbs (3) extract, herbs (1) extract and herbs (3) powder.

It is clear that cellular immunity is better tvdged by testing lymphocytes rather than the phagocytes, and best treatments indicated when feeding in particularly herbs (2) extract and But as noted before least effecting diet (herbs (3) powder) showed pronunnced correction of the immunity (at $42 \%$ improvement). All values of lymphocytes (Table.7) were ever better than that of the control (-) except thus of herbs (3) powder which is of the at most importance for the diabetic patient.

Licoric root (Glycyrrhiza glabral, L.) increased helper T- cell counts, helper - tosuppressor $\mathrm{T}$ - cell ratios improved and liver function improved (Mori et al., 1999). Wang et al.,(2005) found that Artemisia vestita may alleviate contact sensitivity through blocking the activation of $\mathrm{T}$ lymphocytes and decreased inflammatory sites via.

\section{Humoral Immunity}

Data of table (9) and (10)

Alpha, Beta and Gamma Globulins 
Our findings agree with those of Winlers et al., (2006), they found that Allium sativum and Echinacea purpurea modulate the secretion of multiple cytokines. Lee et al., (2006) indicated that black berry, black raspberry, blue berry, strawberry extract inhibit growth and stimulate apoptosis of human cancer cells in vitro. Matos et al., (2006) found that strawberry contains $\operatorname{IgE}$ binding profilim and LTP which lower allergy. Stoev et al., (2010) indicated that artichoke a protective effect of $5 \%$ on humoral immune response (increase of haemagutination). Thejass and Kuttan (2006) noticed that broccoli enhanced production of cytokines IL -2 and IFN gamma. Among herbs contain a variety of phytosterols, terpenes, flavonoids, saponins and carotenoid, which have been shown from studied on legumes, fruits and vegetables to be cancer chemoprotective (Steinmetz and Potter, 1991). Our findings agreement with Drozd and Anuszewska, (2003), they found that Melissa officinalis extract stimulating the immune system, in both humoral and cellular response. Kony et al., (2004) indicated that Astragalus and Angelica could promote both humoral and cellular immune responses and would be expected as the component drug of a new type immunopotentiator. Freier et al., (2003) indicated that Echinacea purpurea enhancement of the antibody forming cell response such as humoral immune responses as well as innate immune responses. Bodient et al., (2004) illustrated that Echinacea purpurea influence on the antibody production of peyer,s patches cells. In the cell of the gut-associated lymphoid tissue and modulate the mucosal immune response. Echinacea purpurea enhancement humoral immunity by measuring total immunoglobulin IgG, IgM. Echinacea purpurea increase production ex vivo - of interferon - gamma byspleen cells and $\operatorname{IgA}$ and interleukin -6 by peyer's patch cells.Different arrangements of humoral immunity were obtained based on alpha, beta and gamma globulin levels. For alpha globulin, best sample was herbs (3) extract, followed by herbs (1) extract, herbs (2) extract, herbs (2) powder \& herbs (1) powder. Best sample based on beta globulin level was herbs (1) extract, herbs (2) powder, herbs (3) extract, herbs (1) powder $\&$ herbs (3) powder.

Best gamma globulin level was found for herbs (3) extract, followed by herbs (3) powder, herbs (2) extract, herbs (1) powder, herbs (2) powder and, herbs (1) extract. While for beta globulin, herbs (3) extract came first, followed by herbs (1) extract, herbs (2) powder, herbs (2) extract. In case of gamma globulin best sample was reduced for herbs (3) extract, herbs (3) powder, herbs (2) extract, herbs (2) powder, herbs (1) powder,herbs (1) extract,. while best sample herbs (3) extract showed $59.28 \%$ improvement.

Serum total protein (TP), albumin (ALB), globulin (Glob) and albumin / globulin ratio (A / B):

\section{Total protein (TP)}

It is evident (Table 11) that due to hyperglycemia, TP was decreased; difference however was insignificant. On the contrary TP increased when feeding rats diets with added botanical materials. treatment showed highest TP, followed by herbs (3) extract diet came first, followed by herbs (2) powder, herbs (1) extract, herbs (2) extract, herbs (1) powder. 
Table.1 Effect of feeding herbs groups (powders \& extracts) on food intake, PER, FER, and BWG (\%) of hyperglycemic rats

\begin{tabular}{|c|c|c|c|c|c|c|c|}
\hline \multirow{3}{*}{$\begin{array}{c}\text { Groups } \\
\text { Variables }\end{array}$} & \multirow{3}{*}{$\begin{array}{c}\text { Control } \\
(+)\end{array}$} & \multicolumn{6}{|c|}{ Herbs } \\
\hline & & \multicolumn{2}{|c|}{ Herbs ( 1 ) } & \multicolumn{2}{|c|}{ Herbs ( 2 ) } & \multicolumn{2}{|c|}{ Herbs ( 3 ) } \\
\hline & & $\begin{array}{c}\text { Powder } \\
\mathbf{2 0 \%}\end{array}$ & $\begin{array}{c}\text { Extract } \\
20 \%\end{array}$ & $\begin{array}{c}\text { Powder } \\
\mathbf{2 0} \%\end{array}$ & $\begin{array}{c}\text { Extract } \\
20 \%\end{array}$ & $\begin{array}{c}\text { Powder } \\
\mathbf{2 0} \%\end{array}$ & $\begin{array}{c}\text { Extract } \\
20 \%\end{array}$ \\
\hline Food intake (g) & $17.1 \pm 0.5^{\mathrm{a}}$ & $14.4 \pm 0.3^{\mathrm{d}}$ & $15.04 \pm .02^{\mathrm{c}}$ & $17.4 \pm 0.3^{\mathrm{a}}$ & $14.3 \pm 0.2^{\mathrm{d}}$ & $17.7 \pm 0.2^{\mathrm{a}}$ & $12.8 \pm 0.1^{\mathrm{e}}$ \\
\hline PER & $-.332 \pm .211^{\mathrm{ab}}$ & $.104 \pm .082^{c}$ & $.238 \pm .137^{\mathrm{bc}}$ & $.646 \pm .115^{\mathrm{a}}$ & $.291 \pm .072^{\mathrm{abc}}$ & $.533 \pm .170^{\mathrm{ab}}$ & $.370 \pm .239^{\mathrm{abc}}$ \\
\hline FER & $-.040 \pm .025^{\mathrm{ab}}$ & $.013 \pm .009^{c}$ & $.029 \pm .017^{\mathrm{bc}}$ & $.078 \pm .013^{\mathrm{a}}$ & $.035 \pm .009^{\mathrm{abc}}$ & $.064 \pm .020^{\mathrm{ab}}$ & $.045 \pm .028^{\mathrm{abc}}$ \\
\hline Initial weight (g) & $149.3 \pm 10.2^{\mathrm{ab}}$ & $161.3 \pm 12.1^{\mathrm{a}}$ & $150.3 \pm 14.4^{\mathrm{ab}}$ & $132.3 \pm 9.3^{\mathrm{b}}$ & $151.7 \pm 7.2^{\mathrm{ab}}$ & $159 \pm 7^{\mathrm{a}}$ & $145.7 \pm 3.9^{\mathrm{ab}}$ \\
\hline Final weight (g) & $130.3 \pm 39.6^{b}$ & $166.3 \pm 10.3^{\mathrm{ab}}$ & $162.3 \pm 7.6^{\mathrm{ab}}$ & $170 \pm 3.6^{\mathrm{a}}$ & $165.7 \pm 9.6^{\mathrm{ab}}$ & $190.6 \pm 3.2^{\mathrm{a}}$ & $161.7 \pm 7.7^{\mathrm{ab}}$ \\
\hline BWG (\%) & $-12.73 \pm 3.3^{\mathrm{ab}}$ & $3.10 \pm 2.6^{c}$ & $7.98 \pm 5.7^{\mathrm{bc}}$ & $28.50 \pm 6.8^{\mathrm{a}}$ & $9.23 \pm 2.1^{b c}$ & $19.87 \pm 7.1^{\mathrm{ab}}$ & $10.98 \pm 8.1^{\mathrm{bc}}$ \\
\hline
\end{tabular}

*Mean \pm SD

Different letters on the values mean significant differences at $\mathrm{P}<0.05 ;(20 \%$ : Herbs $)$.

Table.2 Effect of feeding herbs groups (powders \& extracts) on internal organs weight (g) of hyperglycemic rats

\begin{tabular}{|c|c|c|c|c|c|c|c|}
\hline \multirow{3}{*}{$\begin{array}{c}\text { Groups } \\
\text { Variables }\end{array}$} & \multirow{3}{*}{$\begin{array}{c}\text { Control } \\
(+)\end{array}$} & \multicolumn{6}{|c|}{ Herbs } \\
\hline & & \multicolumn{2}{|c|}{ Herbs (1) } & \multicolumn{2}{|c|}{ Herbs ( 2 ) } & \multicolumn{2}{|c|}{ Herbs ( 3 ) } \\
\hline & & $\begin{array}{c}\text { Powder } \\
20 \%\end{array}$ & $\begin{array}{c}\text { Extract } \\
20 \%\end{array}$ & $\begin{array}{c}\text { Powder } \\
\mathbf{2 0} \%\end{array}$ & $\begin{array}{c}\text { Extract } \\
20 \%\end{array}$ & $\begin{array}{c}\text { Powder } \\
\mathbf{2 0} \%\end{array}$ & $\begin{array}{c}\text { Extract } \\
20 \%\end{array}$ \\
\hline Liver & $3.74 \pm .310^{\mathrm{a}}$ & $4.16 \pm .19^{a}$ & $4.1 \pm .09^{a}$ & $4.7 \pm .72^{a}$ & $3.9 \pm .11^{a}$ & $3.9 \pm .55^{2}$ & $4.06 \pm .21^{2}$ \\
\hline Heart & $.75 \pm .185^{a}$ & $.86 \pm .38^{a}$ & $.68 \pm .22^{a}$ & $.81 \pm .101^{a}$ & & $.68 \pm .19^{a}$ & $.73 \pm .05^{a}$ \\
\hline Kidney & $1.3 \pm .346^{\mathrm{a}}$ & $1.03 \pm .40^{\mathrm{a}}$ & $1.06 \pm .16^{2}$ & $.92 \pm .16^{\mathrm{a}}$ & $.73 \pm .05^{a}$ & $1.09 \pm .09^{2}$ & $1.5 \pm .36^{\mathrm{a}}$ \\
\hline Spleen & $.696 \pm .179^{\mathrm{a}}$ & $.77 \pm .05^{\mathrm{a}}$ & $.72 \pm .15^{\mathrm{a}}$ & $.74 \pm .05^{\mathrm{a}}$ & $1.05 \pm .13^{\mathrm{a}}$ & $.79 \pm .08^{a}$ & $.8 \pm .17^{a}$ \\
\hline Lungs & $1.04 \pm .092^{\mathrm{a}}$ & $1.23 \pm .06^{\circ}$ & $.99 \pm .24^{a}$ & $1.16 \pm .15^{\mathrm{a}}$ & $\begin{array}{l}.73 \pm .03^{a} \\
1.07 \pm .15^{a}\end{array}$ & $1.33 \pm .25^{\mathrm{a}}$ & $1.13 \pm .20^{2}$ \\
\hline
\end{tabular}

$*$ Mean \pm SD; Different letters on the values mean significant differences at $\mathrm{P}<0.05 ;(20 \%$ :Herbs $)$. 
Table.3 Effect of feeding herbs groups (powders \& extracts) on blood glucose level ( $\mathrm{mg} / \mathrm{dl}$ ) of hyperglycemic rats

\begin{tabular}{|c|c|c|c|c|c|c|c|c|}
\hline \multirow{3}{*}{ Variables } & \multirow{2}{*}{\multicolumn{2}{|c|}{ Control }} & \multicolumn{6}{|c|}{ Herbs } \\
\hline & & & \multicolumn{2}{|c|}{ Herbs ( 1 ) } & \multicolumn{2}{|c|}{ Herbs ( 2 ) } & \multicolumn{2}{|c|}{ Herbs ( 3 ) } \\
\hline & $(-)$ & $(+)$ & $\begin{array}{c}\text { Powder } \\
\mathbf{2 0 \%}\end{array}$ & $\begin{array}{c}\text { Extract } \\
20 \%\end{array}$ & $\begin{array}{c}\text { Powder } \\
20 \%\end{array}$ & $\begin{array}{c}\text { Extract } \\
20 \%\end{array}$ & $\begin{array}{c}\text { Powder } \\
20 \%\end{array}$ & $\begin{array}{c}\text { Extract } \\
20 \%\end{array}$ \\
\hline Serum glucose & $84 \pm 2^{f}$ & $149.3 \pm 1.02^{a}$ & $97.3 \pm .5^{\mathrm{e}}$ & $104.3 \pm 3.05^{\mathrm{d}}$ & $94.6 \pm .03^{\mathrm{e}}$ & $93.6 \pm 2.5^{\mathrm{e}}$ & $116.6 \pm 2.5^{\mathrm{c}}$ & $137.3 \pm 3.5^{b}$ \\
\hline $\begin{array}{l}\% \text { decrease of } \\
\text { control (+) }\end{array}$ & -43.7 & - & -34.8 & -30.1 & -36.6 & -37.3 & -21.9 & -8.0 \\
\hline $\begin{array}{l}\% \text { decrease of } \\
\text { control (-) }\end{array}$ & - & +77.7 & - & +15.8 & +12.6 & +11.4 & +11.4 & +63.5 \\
\hline
\end{tabular}

$* *$ Mean \pm SD

Different letters on the values mean significant differences at $\mathrm{P}<0.01$.

$20 \%$ : Herbs

Table.4 Effect of feeding herbs groups (powders \& extracts) on fasting serum lipids profile of hyperglycemic rats

\begin{tabular}{|c|c|c|c|c|c|c|c|c|}
\hline \multirow{3}{*}{$\begin{array}{l}\text { Variables } \\
\text { ( } \mathrm{mg} / \mathrm{dl})\end{array}$} & \multirow{2}{*}{\multicolumn{2}{|c|}{ Control }} & \multicolumn{6}{|c|}{ Herbs } \\
\hline & & & \multicolumn{2}{|c|}{ Herbs ( 1 ) } & \multicolumn{2}{|c|}{ Herbs ( 2 ) } & \multicolumn{2}{|c|}{ Herbs ( 3 ) } \\
\hline & $(-)$ & $(+)$ & $\begin{array}{c}\text { Powder } \\
20 \%\end{array}$ & $\begin{array}{c}\text { Extract } \\
20 \%\end{array}$ & $\begin{array}{c}\text { Powder } \\
20 \%\end{array}$ & $\begin{array}{c}\text { Extract } \\
20 \%\end{array}$ & $\begin{array}{c}\text { Powder } \\
\mathbf{2 0 \%}\end{array}$ & $\begin{array}{c}\text { Extract } \\
\mathbf{2 0 \%}\end{array}$ \\
\hline Cholesterol & $119.3 \pm .52^{\mathrm{b}}$ & $146.6 \pm .51^{\mathrm{a}}$ & $81.6 \pm 8.5^{\mathrm{f}}$ & $93.6 \pm 5.03^{\mathrm{e}}$ & $118 \pm 2^{b}$ & $92.3 \pm 4.5^{\mathrm{e}}$ & $107.3 \pm 7.5^{\mathrm{cd}}$ & $101 \pm 3^{\text {de }}$ \\
\hline Triglyceride & $97 \pm 3^{b c}$ & $102 \pm 4^{a}$ & $97 \pm 4^{b}$ & $67 \pm 3^{\mathrm{e}}$ & $101 \pm 2^{\mathrm{a}}$ & $65 \pm 4^{\text {ef }}$ & $62 \pm 5^{\mathrm{f}}$ & $83 \pm 7^{c}$ \\
\hline $\mathrm{HDL}$ & $55.7 \pm 2.52^{\mathrm{a}}$ & $36.7 \pm 3.51^{b}$ & $41.7 \pm 5.03^{\mathrm{a}}$ & $37.7 \pm 12.5^{\mathrm{a}}$ & $44 \pm 4^{\mathrm{a}}$ & $42.3 \pm 4.5^{\mathrm{a}}$ & $40.6 \pm 3.5^{\mathrm{a}}$ & $46.7 \pm 10.02^{\mathrm{a}}$ \\
\hline LDL & $44.2 \pm 2.2^{\mathrm{b}}$ & $89.5 \pm 4.3^{\mathrm{a}}$ & $20.5 \pm 3.3^{\mathrm{e}}$ & $42.5 \pm 2.1^{\mathrm{c}}$ & $53.8 \pm 4.1^{\mathrm{b}}$ & $37.0 \pm 6.2^{\mathrm{d}}$ & $54.3 \pm 4.3^{\mathrm{b}}$ & $37.7 \pm 2.2^{c}$ \\
\hline VLDL & $19.4 \pm 2^{\mathrm{a}}$ & $20.4 \pm 3^{a}$ & $19.4 \pm 6.3^{\mathrm{bc}}$ & $13.4 \pm 2.2^{\mathrm{de}}$ & $20.4 \pm 1^{\mathrm{ab}}$ & $13.0 \pm 3.1^{\mathrm{a}}$ & $12.4 \pm 3.3^{\mathrm{de}}$ & $16.6 \pm 1.3^{\mathrm{bcd}}$ \\
\hline
\end{tabular}

Mean \pm SD

*Different letters on the values mean significant differences at $\mathrm{P}<0.05$.

$* *$ Different letters on the values mean significant differences at $\mathrm{P}<0.01$.

$20 \%$ : Herbs 
Table.5 Effect of feeding herbs groups (powders \& extracts) on liver function of hyperglycemic rats

\begin{tabular}{|c|c|c|c|c|c|c|c|c|}
\hline \multirow{3}{*}{$\begin{array}{c}\text { Variables } \\
(\mathrm{U} / \mathrm{L})\end{array}$} & \multirow{2}{*}{\multicolumn{2}{|c|}{ Control }} & \multicolumn{6}{|c|}{ Herbs } \\
\hline & & & \multicolumn{2}{|c|}{ Herbs ( 1 ) } & \multicolumn{2}{|c|}{ Herbs ( 2 ) } & \multicolumn{2}{|c|}{ Herbs ( 3 ) } \\
\hline & $(-)$ & $(+)$ & $\begin{array}{c}\text { Powder } \\
\mathbf{2 0 \%}\end{array}$ & $\begin{array}{c}\text { Extract } \\
20 \%\end{array}$ & $\begin{array}{c}\text { Powder } \\
20 \%\end{array}$ & $\begin{array}{c}\text { Extract } \\
20 \%\end{array}$ & $\begin{array}{c}\text { Powder } \\
\mathbf{2 0 \%}\end{array}$ & $\begin{array}{c}\text { Extract } \\
20 \%\end{array}$ \\
\hline $\begin{array}{c}\text { Liver } \\
\text { Enzymes }\end{array}$ & & & & & & & & \\
\hline GPT & $26 \pm 2^{b c}$ & $83.3 \pm 4.51^{a}$ & $29.3 \pm 4.5^{b c}$ & $26 \pm 6^{c}$ & $34.6 \pm 4.5^{b c}$ & $25.3 \pm 2.5^{c}$ & $24.3 \pm 4.5^{c}$ & $45 \pm 5^{b}$ \\
\hline GOT & $62.3 \pm 2.52^{\mathrm{d}}$ & $150.3 \pm 2.52^{\mathrm{a}}$ & $70.6 \pm 6.02^{c}$ & $63.3 \pm 6.5^{c}$ & $75.3 \pm 3.5^{c}$ & $63 \pm 5.5^{c}$ & $62.6 \pm 8.02^{c}$ & $\begin{array}{c}118.6 \pm \\
7.02^{\mathrm{b}}\end{array}$ \\
\hline
\end{tabular}

$* *$ Mean $\pm \mathrm{SD}$

Different letters on the values mean significant differences at $\mathrm{P}<0.01$.

$20 \%$ : Herbs

Table.6 Effect of feeding herbs groups (powders \& extracts) on kidneys function of hyperglycemic rats

\begin{tabular}{|c|c|c|c|c|c|c|c|c|}
\hline \multirow{3}{*}{\begin{tabular}{l}
\multicolumn{1}{c}{ Groups } \\
Variables \\
(mg/dl)
\end{tabular}} & \multirow{2}{*}{\multicolumn{2}{|c|}{$\begin{array}{c}\text { Control } \\
(+)\end{array}$}} & \multicolumn{6}{|c|}{ Herbs } \\
\hline & & & \multicolumn{2}{|c|}{ Herbs ( 1 ) } & \multicolumn{2}{|c|}{ Herbs ( 2) } & \multicolumn{2}{|c|}{ Herbs ( 3 ) } \\
\hline & $(-)$ & $(+)$ & $\begin{array}{c}\text { Powder } \\
20 \%\end{array}$ & $\begin{array}{c}\text { Extract } \\
20 \%\end{array}$ & $\begin{array}{c}\text { Powder } \\
20 \%\end{array}$ & $\begin{array}{c}\text { Extract } \\
20 \%\end{array}$ & $\begin{array}{c}\text { Powder } \\
20 \%\end{array}$ & $\begin{array}{c}\text { Extract } \\
20 \%\end{array}$ \\
\hline $\begin{array}{l}\text { Renal } \\
\text { Indices }\end{array}$ & $.82 \pm .03^{\mathrm{bc}}$ & $1.5 \pm 0.4^{a}$ & $.503 \pm .355^{\mathrm{b}}$ & $.793 \pm .025^{\mathrm{ab}}$ & $.507 \pm .390^{\mathrm{b}}$ & $.947 \pm .351^{\mathrm{ab}}$ & $.88 \pm .351^{\mathrm{ab}}$ & $1.05 \pm .02^{\mathrm{ab}}$ \\
\hline Urea & $26 \pm 4^{\mathrm{d}}$ & $50 \pm 3^{\mathrm{a}}$ & $35.67 \pm .51^{\mathrm{cd}}$ & $41.33 \pm 4.51^{b}$ & $33.67 \pm .51^{\mathrm{de}}$ & $36.33 \pm .51^{\mathrm{cd}}$ & $41.67 \pm .51^{\mathrm{b}}$ & $39.33 \pm 2.51^{\mathrm{bc}}$ \\
\hline Uric acid & $2.23 \pm 25^{\mathrm{ab}}$ & $2.77 \pm .075^{\mathrm{a}}$ & $2.57 \pm .35^{a}$ & $1.53 \pm .35^{\mathrm{b}}$ & $2.6 \pm .3^{\mathrm{a}}$ & $1.33 \pm .252^{\mathrm{b}}$ & $1.57 \pm .153^{b}$ & $2.56 \pm .35^{\mathrm{a}}$ \\
\hline
\end{tabular}

**Mean \pm SD

Mean with different letters on the values denote significant differences at $\mathrm{P}<0.01$.

$20 \%$ : Herbs 
Table.7 Effect of feeding herbs groups (powders \& extracts) on cellular immunity (phagocytes \& lymphocytes) of hyperglycemic rats

\begin{tabular}{|c|c|c|c|c|c|c|c|c|}
\hline \multirow{3}{*}{ Variables } & \multirow{2}{*}{\multicolumn{2}{|c|}{ Control }} & \multicolumn{6}{|c|}{ Herbs } \\
\hline & & & \multicolumn{2}{|c|}{ Herbs ( 1 ) } & \multicolumn{2}{|c|}{ Herbs ( 2 ) } & \multicolumn{2}{|c|}{ Herbs ( 3 ) } \\
\hline & (1) & $(+)$ & $\begin{array}{c}\text { Powder } \\
20 \% \\
\end{array}$ & $\begin{array}{c}\text { Extract } \\
20 \%\end{array}$ & $\begin{array}{c}\text { Powder } \\
20 \%\end{array}$ & $\begin{array}{c}\text { Extract } \\
20 \%\end{array}$ & $\begin{array}{c}\text { Powder } \\
20 \%\end{array}$ & $\begin{array}{c}\text { Extract } \\
20 \%\end{array}$ \\
\hline Phagocytes & $75 \pm 9^{a}$ & $70 \pm 7^{\mathrm{a}}$ & $80 \pm 17^{\mathrm{a}}$ & $81 \pm 14^{a}$ & $82 \pm 9^{\mathrm{a}}$ & $81 \pm 25^{\mathrm{a}}$ & $85 \pm 27.51^{a}$ & $83 \pm 40^{\mathrm{a}}$ \\
\hline Lymphocytes & $1.33 \pm 12^{\mathrm{ab}}$ & $0.91 \pm .03^{\mathrm{b}}$ & $1.66 \pm .15^{\mathrm{ab}}$ & $1.54 \pm 0.2^{\mathrm{ab}}$ & $1.66 \pm .27^{\mathrm{ab}}$ & $1.92 \pm .07^{\mathrm{a}}$ & $1.29 \pm .265^{\mathrm{b}}$ & $1.64 \pm .33^{\mathrm{ab}}$ \\
\hline
\end{tabular}

Mean \pm SD

* Different letters on the values denote significant differences at $\mathrm{P}<0.05$.

$* *$ Different letters on the values denote significant differences at $\mathrm{P}<0.01$.

$20 \%$ : Herbs

Table.8 Effect of feeding herbs groups (powders \& extracts) on cellular immunity (phagocytes \& lymphocytes) of hyperglycemic rats (\%

$$
\text { increase of control +) }
$$

\begin{tabular}{|c|c|c|c|c|c|c|c|}
\hline \multirow{3}{*}{$\begin{array}{l}\text { Groups } \\
\text { Variables }\end{array}$} & \multirow{3}{*}{$\begin{array}{l}\text { Control } \\
(+)\end{array}$} & \multicolumn{6}{|c|}{ Herbs } \\
\hline & & \multicolumn{2}{|c|}{ Herbs (1) } & \multicolumn{2}{|c|}{ Herbs (2) } & \multicolumn{2}{|c|}{ Herbs ( 3 ) } \\
\hline & & $\begin{array}{c}\text { Powder } \\
20 \%\end{array}$ & $\begin{array}{c}\text { Extract } \\
20 \%\end{array}$ & $\begin{array}{c}\text { Powder } \\
20 \%\end{array}$ & $\begin{array}{c}\text { Extract } \\
20 \%\end{array}$ & $\begin{array}{l}\text { Powder } \\
20 \%\end{array}$ & $\begin{array}{c}\text { Extract } \\
20 \%\end{array}$ \\
\hline $\begin{array}{l}\% \text { Phagocytes of } \\
\text { control }(+)\end{array}$ & $\ldots$ & +14.29 & +15.71 & +17.14 & +15.71 & +21.43 & +18.57 \\
\hline $\begin{array}{l}\% \text { Lymphocytes of } \\
\text { control }(+)\end{array}$ & $\cdots$ & +82.42 & +69.23 & +82.42 & +110.99 & +41.76 & +80.22 \\
\hline
\end{tabular}

(\% of control " + "). 20\% : Herbs 
Table.9 Effect of feeding herbs groups (powders \& extracts) on humoral immunity of hyperglycemic rats (Globulins fractions)

\begin{tabular}{|c|c|c|c|c|c|c|c|c|}
\hline \multirow{3}{*}{\begin{tabular}{l}
\multicolumn{1}{c}{ Groups } \\
Variables \\
(g/dl )
\end{tabular}} & \multirow{2}{*}{\multicolumn{2}{|c|}{$\begin{array}{c}\text { Control } \\
(+)\end{array}$}} & \multicolumn{6}{|c|}{ Herbs } \\
\hline & & & \multicolumn{2}{|c|}{ Herbs ( 1 ) } & \multicolumn{2}{|c|}{ Herbs ( 2 ) } & \multicolumn{2}{|c|}{ Herbs ( 3 ) } \\
\hline & $(-)$ & $(+)$ & $\begin{array}{c}\text { Powder } \\
20 \%\end{array}$ & $\begin{array}{c}\text { Extract } \\
20 \%\end{array}$ & $\begin{array}{c}\text { Powder } \\
20 \%\end{array}$ & $\begin{array}{c}\text { Extract } \\
20 \%\end{array}$ & $\begin{array}{c}\text { Powder } \\
20 \%\end{array}$ & $\begin{array}{c}\text { Extract } \\
20 \%\end{array}$ \\
\hline $\begin{array}{l}\text { GLOBULI } \\
\text { NS } \\
\text { ALPHA } \\
\text { BETA } \\
\text { GAMMA }\end{array}$ & $\begin{array}{l}1.27 \pm .014^{\mathrm{ab}} \\
1.41 \pm 0.1^{\mathrm{a}} \\
1.85 \pm .04^{\mathrm{d}}\end{array}$ & $\begin{array}{l}1.15 \pm 027^{\mathrm{abc}} \\
1.21 \pm 0.1^{\mathrm{ab}} \\
1.67 \pm .11^{\mathrm{e}}\end{array}$ & $\begin{array}{l}1.09 \pm .06^{\mathrm{c}} \\
1.14 \pm .07^{\mathrm{a}} \\
2.31 \pm 0.1^{\mathrm{b}}\end{array}$ & $\begin{array}{l}1.32 \pm 09^{\mathrm{ab}} \\
1.27 \pm .06^{\mathrm{a}} \\
2.15 \pm .1^{\mathrm{bc}}\end{array}$ & $\begin{array}{l}1.19 \pm .07^{\mathrm{a}} \\
1.25 \pm .11^{\mathrm{a}} \\
2.31 \pm .08^{\mathrm{b}}\end{array}$ & $\begin{array}{c}1.21 \pm .07^{\mathrm{bc}} \\
1.19 \pm .07^{\mathrm{a}} \\
2.35 \pm .08^{\mathrm{b}}\end{array}$ & $\begin{array}{c}1.15 \pm .14^{\mathrm{bc}} \\
1.05 \pm .04^{\mathrm{a}} \\
2.61 \pm .1^{\mathrm{a}}\end{array}$ & $\begin{array}{l}1.41 \pm .08^{\mathrm{a}} \\
1.14 \pm .11^{\mathrm{a}} \\
2.66 \pm .08^{\mathrm{a}}\end{array}$ \\
\hline
\end{tabular}

Different letters on the values mean significant differences at $\mathrm{P}<0.05$.

$20 \%$ : Herbs

Table.10 Effect of feeding herbs groups (powders \& extracts) on humoral immunity of hyperglycemic rats (Globulins fractions) \% increase of control (+)

\begin{tabular}{|c|c|c|c|c|c|c|c|}
\hline \multirow{3}{*}{ Variables } & \multirow{3}{*}{$\begin{array}{c}\text { Control } \\
(+)\end{array}$} & \multicolumn{6}{|c|}{ Herbs } \\
\hline & & \multicolumn{2}{|c|}{ Herbs ( 1 ) } & \multicolumn{2}{|c|}{ Herbs ( 2 ) } & \multicolumn{2}{|c|}{ Herbs ( 3 ) } \\
\hline & & $\begin{array}{c}\text { Powder } \\
\mathbf{2 0} \%\end{array}$ & $\begin{array}{c}\text { Extract } \\
\mathbf{2 0} \%\end{array}$ & $\begin{array}{c}\text { Powder } \\
\mathbf{2 0} \%\end{array}$ & $\begin{array}{c}\text { Extract } \\
\mathbf{2 0} \%\end{array}$ & $\begin{array}{c}\text { Powder } \\
\mathbf{2 0} \%\end{array}$ & $\begin{array}{c}\text { Extract } \\
20 \%\end{array}$ \\
\hline $\begin{array}{l}\text { GLOBULINS : } \\
\% \text { ALPHA of } \\
\text { control (+) }\end{array}$ & $\ldots$ & -5.22 & +14.78 & +3.48 & +5.22 & +0 & +22.61 \\
\hline $\begin{array}{l}\% \text { BETA of } \\
\text { control }(+)\end{array}$ & - & -5.79 & +4.96 & +3.31 & -1.65 & -13.22 & -5.79 \\
\hline $\begin{array}{l}\% \text { GAMMA of } \\
\text { control }(+)\end{array}$ & - & +38.32 & +28.74 & +38.32 & +40.72 & +56.29 & $+\mathbf{5 9 . 2 8}$ \\
\hline
\end{tabular}

$(\%$ of control " $+") ; 20 \%:$ Herbs. 
Table.11 Effect of feeding herbs groups (powders\& extracts) on some humoral immunity indices of hyperglycemic rats (total protein " TP ",

albumin "ALB", total globulin "GLOB" and A/B ratio)

\begin{tabular}{|c|c|c|c|c|c|c|c|c|}
\hline \multirow{3}{*}{ Variables } & \multirow{2}{*}{\multicolumn{2}{|c|}{$\begin{array}{c}\text { Control } \\
(+)\end{array}$}} & \multicolumn{6}{|c|}{ Herbs } \\
\hline & & & \multicolumn{2}{|c|}{ Herbs ( 1 ) } & \multicolumn{2}{|c|}{ Herbs ( 2 ) } & \multicolumn{2}{|c|}{ Herbs ( 3 ) } \\
\hline & $\begin{array}{c}\text { Control } \\
(-)\end{array}$ & $\begin{array}{c}\text { Control } \\
(+)\end{array}$ & $\begin{array}{c}\text { Powder } \\
\mathbf{2 0} \%\end{array}$ & $\begin{array}{c}\text { Extract } \\
\mathbf{2 0} \%\end{array}$ & $\begin{array}{c}\text { Powder } \\
20 \%\end{array}$ & $\begin{array}{c}\text { Extract } \\
\mathbf{2 0} \%\end{array}$ & $\begin{array}{c}\text { Powder } \\
\mathbf{2 0} \%\end{array}$ & $\begin{array}{c}\text { Extract } \\
\mathbf{2 0} \%\end{array}$ \\
\hline TP (g/dl ) & $6.58 \pm .017^{\circ}$ & $6.05 \pm .07^{\circ}$ & $6.93 \pm .02^{\mathrm{ab}}$ & $7.1 \pm 1^{\mathrm{ab}}$ & $7.07 \pm .02^{\mathrm{ab}}$ & $6.99 \pm .03^{\mathrm{ab}}$ & $7.22 \pm .01^{\text {ab }}$ & $7.64 \pm 0.07^{a}$ \\
\hline $\operatorname{ALB}(g / d l)$ & $2.32 \pm .09^{\mathrm{a}}$ & $2.02 \pm .004^{b}$ & $2.39 \pm .03^{2}$ & $2.36 \pm .05^{\mathrm{a}}$ & $2.32 \pm .04^{2}$ & $2.24 \pm .06^{b}$ & $2.41 \pm .05^{3}$ & $2.43 \pm .08^{a}$ \\
\hline GLOB ( $\mathbf{g}$ / & $4.53 \pm 009^{\circ}$ & $4.03 \pm .014^{d}$ & $4.54 \pm .07^{4}$ & $4.74 \pm .05^{\mathrm{be}}$ & $4.75 \pm .06^{b c}$ & $4.75 \pm .04^{\text {be }}$ & $4.81 \pm .04^{b}$ & $5.21 \pm .04^{2}$ \\
\hline $\begin{array}{c}\text { dl) } \\
\text { A / B ( g / dl ) }\end{array}$ & 0.5 & 0.501 & .526 & .498 & .488 & .472 & .501 & .466 \\
\hline
\end{tabular}

$*$ Mean \pm SD

Different letters on the values mean significant differences at $\mathrm{P}<0.05$.

A / B : Albumin to globulin ratio.

$20 \%$ : Herbs

Overall, the best treatment was recorded for herbs (3) extract, herbs (2) powder, herbs (1) extract.

\section{Albumin (ALB)}

ALB decreased by hyperglycemia and increased by different treatments came first herbs (3) extract, followed by herbs (3) powder, herbs (1) powder, herbs (1) extract, herbs (2) powder, herbs (2) extract. All tested plants could be arranged descendingly for ALB as follows: Herbs (3) extract, herbs (3) powder, herbs (1) powder, herbs (1) extract, herbs (2) powder, herbs (2) extract. which showed least effect caused $9.41 \%$ improvement of ALB, while the best treatment (Herbs "3" extract) caused 19.31 $\%$ increase in ALB compared to control (+) group.

Jafary et al., (2006) found that barley play a role as specific and quantitative recognition factors that are specially negated by the rust to successfully innate immunity. Our findings disagreement with Mansour et al., (2002), they found that lupinus albus, L. (lupinus termis) and Cymbop ogan proximus, (Halfa barr) decrease total protein and albumin significantly by 25 and $46 \%$ respectively. Adzet et al., (2000) found that artichoke leaf extract show a concentration. Dependent inhibitory activity in the above models, contributing to the antioxidant activity of the extract in human neutrophils. Jia et al., (2006) they observed that Angelica sinensis - polysaccharide could regulate the immune response through upregulating IL -2 , IfN -gamma expression and activating Th 1 cell. They found that the petic polysaccharide activates the immune functions of B cells and macrophages. They added that Echinacea is commonly used in oral dosage as an immune stimulant to increase resistance to viral, bacterial and fungal infections of the upper respiratory tract including those regulated by macrophages and natural killer cells. Aviello and RowlandI,(2014).

\section{Serum globulin (GLOB)}

Total globulins (Table 11) declined by hyperglycemia and improved by different 
feeding treatments, following nearly the same arrangement as that of gamma globulin (Table11) Highest improvement of $\mathrm{T}$. globulins. Herbs (3) extract, herbs (3) powder, herbs (2) powder, herbs (2) extract, herbs (1) extract, \& herbs (1) powder. Considering all plants tested, best sample was the herbs (3) extract, followed by herbs (2) powder, herbs (2) extract, herbs (1) extract, herbs (1) powder. The best treatment (herbs "3" extract) revealed $29.28 \%$ increase of T. globulins as compared to that of control (+) groups.

\section{References}

Adzet, T., Perez, Garcia F. and Canigueral, S. (2000) : Activity of artichoke leaf extract on reactive oxygen species in human leukocytes. J. of Free Radic. Res., 33 (5) : 661-665.

Ahmed, Reham R.A.S. (2010) : Therapeutic Effects of Leaves Obtained From Some Common Trees in Egypt on the Experimental Rats. M. Sc. Thesis, Faculty of Home Economics, Minufiya University

American Diabetes Association (ADA) (1995a) : Nutrition recommendations and principles for people with diabetes mellitus (Position Statement). Diabetes Care 18 (Suppl) : 16 .

American Diabetes Association (2001) : Screening for diabetes. Diabetes care 24 (suppl) :521-524.

American Diabetes Association(2014):. Standards of medical care for diabetes -. Diabetes Care, 2014, 37 Supplement

Amos, A.F., Mc Carty, D.J. and Zimment, P. (1997) : The rising global burden of diabetes and its complications : Estimate and projections to the year 2010. Diabet. Med. 14-57-585.

Aviello,G. I. and Rowland, C. I.(2014):
"Anti-proliferative effect of rhein, an anthraquinone isolated fromCassia species, on Caco-2 human adenocarcinoma cells," Journal of Cellular and Molecular Medicine, vol. 14, no. 7, pp. 2006-2014, 2010., 54 (2) : 114-118.

Boyum, A. (1968) : Isolation of mononuclear cells \& granulocytes from human blood. Scand. J. Clin. Lab. Invest., $21: 77$.

Burrels, S. and Wells, P. W. (1977) : Invitro stimulation of ovine lymphocytes. Res.Vet. Sci., 23 : 8486.

Carawy, W. (1955) : Uric acid colorimetric method. Am. J. Clin. Path. (25) : 840. Chapman, D.G, Castilla, R. and Campbell, J. A. (1959) : Evaluation of protein in food I : A method for the determination of protein efficiency ratio. Can. J. Biochem. Physiol., 37 : 679 - 686.

Denise, I., Bounous, A., Raymond, Q., Compagnoli, A. and John Brown, B. (1992) : Comprison of MTT colorimetric assay \& tritiated thymidiue uptake for lymphocyte proliferation assay using chicken splenlocytes. Avian Dis., 36 :10221027.

Desai, A. and Bhide, M. (1985): Hypoglycemic effect of Hanitonia suavcolens. Indian. J.Med., 81: 8691.

Drozd, J. and Anuszewska, E. (2003): The effect of the Melissa officinalis extract on immune response in mice. J. of Acta Pol. Pharm., 60 (6) : 467470.

Drury, R. A. and Wallington, E.A. (1980) : Carlton,s Histological Technique. 5th Ed.Oxford Univ.

Dunne, Lavon J. (2001) : Nutrition Almanac. 5 th Ed. Pub, by Mc. Graw-Hill. New York Chicago. 76- 
77.

Eidi, A., Eidi, M. and Esmaeili, E. (2006) : Antidiabetic effect of garlic (Allium sativum L.) in normal and streptozotocin-induced diabetic rats. J. of Phytomedicine., 13 (9-10) : 624-629.

El-Sayed, H.H. (2001) : Biological Studies on the Effect of Portulaca oleracea, L. on Lowering Lipids and Blood Sugar in Experimental Animals. Ph. D Thesis, Faculty of Home Economics. Minufiya University.

Fawcette, J.K. and Scott, J.E.(1960):A rapid and precise method for the determination of blood urea. J.Clin.Pathol., 13, 156-159.

Freier, D.O., Wright, K., Klein, K., Voll, D., Dabiri, K., Cosulich, K. and George, R. (2003) : Enhancement of the humoral immune response by Echinacea purpureain female Swiss mice. J. of Immunopharmacol. Immunotoxicol., 25 (4) : 551-560.

Ghamry, Heba I. (2004) : Effect of the Different Processing of Fenugreek Seeds on Blood Glucose Level in Rats. M. SC. Thesis, Faculty of Home Economies, Minufiya Univ. Gordon, T. and Amer, M. (1977) : Determination of HDL. J. Med., 62 : 707.

Hegsted, A. (1941): Salt mixture. J. Biol. Chem., 138: 459.

Henry, D.S. (1974) : Clinical Chemist : Principles and technics, 2nd Edition, Hagerstown (MD), Harcer, Row, P. 882.

Herrera, Arellano A., Aguilar,Santamaria L., Garcia, Hernandez B., Nicasio, Torres P. and Tortoriello, J. (2004) : Clinical trial of Cecropia obtusifolia and Marrubium vulgare leaf extracts on blood glucose and serum lipids in type 2 diabetics. J. of Phytomedicine, 11 (7-8) : 561-566.
Hudson, L. and Hay, F. C. (1980) : Immunology.2nd ed. Black-Well Scientific Publication.Oxford, London, Edinburgh, Boston, Melbourve.

Jacobs, N.J. and Van Denmark, P.J. (1960) : Determination of triglycerides. Arch. Biochem. Biophys., 88 : 250-255.

Jia, M., Yang, T.H. and Mei, Q.B.(2006) : Effect of Angelica sinensis polysaccharide fraction AP-3 on IL-2 and IFN-gamma induction. J. of Yao Xue Xue Bao, 41(1) : 54-57.

Khalil, A., Berrougui, H. and Isabelle, M., Cherki, M., (2006) : Marrubium vulgare extract inhibits human-LDL oxidation and enhances HDLmediated cholesterol efflux in THP-1 macrophage. J. of Life Sci., 54 (3) : 64-72.

Kim, C. , Kany, S. , Jeony, G. , Cheong, C. K. , Kim, B. , Huh, H., Kang, S.H , Jeong, G. W. , Cheong, C.S., Kim, C.Y., Kim, B.K. and Huh.H.(2015): Mulberry Leaf Extract and Blood Glucose Control in Diabetics. Korean Journal of Pharmacognosy, 31(1) : 95-100.

Kony, X., Hu, Y., Rui, R., Wang, D. and Li, X. (2004) : Effects of Chinese herbal medicinal ingredients on peripheral lymphocyte proliferation and serum antibody titer after vaccination in chicken. J. of Int. Immunopharmacol., 4 (7) : 975-982.

Korkmaz, H. and Gurdal, A. (2002) : Effect of Artemisia santonicum L. on blood glucose in normal and alloxaninduced diabetic rabbits. J. of Phytother. Res., 16 (7) : 675-676.

Laemmli, U. K. (1970) : Structural proteins during the assembly of the head of bacteriophage T4. Nature, 227 (15) : 680-685.

Larsen, K. (1972) : Creatinine coloremitric kinetic method. J. of Clin. Chem., 
(41) : 209

Lau, C.B., Li, J.M., Che, C.T., Leung, P.S. and Cheng, C.H. (2006) : Desoxyrhaponticin (3,5-Dihydroxy4'-methoxystilbene 3-O-\{beta $\}-\mathrm{D}$ glucoside) inhibits Glucose Uptake in the Intestine and Kidney: In vitro and in vivo studies. J. of Pharmacol. Exp. Ther., 10 (7) : 17-20.

Lee, K.H., Han, S.B., Lee, C.W., Kang, M.R., Yoon, Y.D., Kang, J.S., Yoon, W.K., Lee, K., Park, S.K. and Kim, H.M. (2006) : Pectic polysaccharide isolated from Angelica gigas Nakai inhibits melanoma cell metastasis and growth by directly preventing cell adhesion and activating host immune functions. J. of Cancer Lett., 243 (2) : 264-273.

Lee, R.D and Nieman, D.C (1996) : Nutritional Assessment. 2nd Ed. Mosby, Missoun, USA.

Lee, R.D. and Nieman, D.C. (2003) : Nutritional Assessment. 3rd. Pub, by Mc. Graw-Hill. Avenue of the Americans, New York. s287.

Mansour, H.A., Newairy, A.S., Yousef, M.I. and Sheweita, S.A. (2002) : Biochemical study on the effects of some Egyptian herbs in alloxaninduced diabetic rats. J. of Toxicology, 170 (3) : 221-228.

Matos, C.I., Zuidmeer, L., Salentijn, E., Rivas, M.F., Mancebo, E.G., Asero, R., Pelgrom, K.T., Gilissen, LJ. and Ree, R. (2006) : The role of profiling and lipid transfer protein in strawberry allergy in the Mediterranean area. J. of Clin. Exp. Allergy, 36 (5) : 666-675.

Mohamed, Manal. A. (2006) : The Effect of Some Nuts on Hyperglycemic and hypercholesterolemic rats. M. Sc. Thesis, Faculty of Home Economics, Helwan University.

Mori, K., Sakai, H., Suzuki, S., Akutsu, Y.,
Ishikawa, M., Aihara, M., Yokoyama, M., Sato, Y., Okaniwa, S. and Endo, Y. (1999) : The present status in prophylaxis and treatment of HIV infected patients with hemophilia in Japan. Rinsho Byhori, $37: 1200$.

Nada, S.A. , Bashandy, S.A.E. and Negm. S.A. (1997): Evaluation of the hypoglycemic activity of a traditional herbal preparation in male diabetic rats. Fitoterapia, 68 (3): 240244.

Nation Diabetes Data Group (NDDG) (1994): Classification and diagnosis of diabetes mellitus and other categories of glucose intolerance. Diabetes, 28 : 1039 -1057.

Rai-El-Balahaa, G., Pellerin. J. L., Bodin, G., Abdullah, H. A. and Hiron, H. (1985) : Lymphoplastic transformation assay of sheep peripheral blood lymphocytes : A new rapid and easy to read techniques. Comp. Immune. Microbiol. Infec. Dis., 8 : 311-318.

Reeves, P.G., Nielson, F.H. and Fahmy, G.C. (1993): Reports of the American Institute of Nutrition, adhoc willing committee on reformulation of the AIN 93, Rodent diet. J. Nutri.,123:1939-1951.

Saad, Gehan G.A.A. (2006) : Biological Study The Probable Medical Action of Some Common and Uncommon Botanical Parts in Man, s Diet. M. Sc. Thesis, Faculty of Home Economics, Minufiya Univ.

Sauls, D.L. Banini, A.E., Boyd, L.C., Allen, J.C., Allen, H.G. and (2006) : Muscadine grape products intake, diet and blood constituents of nondiabetic and type 2 diabetic subjects. J. of Nutrition, 22 (11-12) : 11371145.

SPSS. (1998) : Statistical Package for Social 
Science, Computer Software, Ver.10, SPSS Company, London, UK.

Stoev, S.D., Anguelov, G., Ivanov, I. and Pavlov, D. (2010) : Influence of ochratoxin A and an extract of artichoke on the vaccinal immunity and health in broiler chicks.J. of Exp. Toxicol. Pathol., 52 (1) : 43-55.

Thejass, P. and Kuttan, G. (2006) : Augmentation of natural killer cell and antibodydependent cellular cytotoxicity in $\mathrm{BALB} / \mathrm{c}$ mice by sulforaphane, a naturally occurring isothiocyanate from broccoli through enhanced production of cytokines IL-2 and IFN-gamma. J. of Immunopharmacol. Immunotoxicol., 28(3) : 443-457.

Tietz, N.W. (1976) : Fundamentals of Clinical Chemistry. Philade Iphia, W.B. Saunders, P 243.

Tyler, V. (1994) : Herbs of Choice : The Therapeutic Use of Phytomedicinals. Pharmaceutical Products Press, New York.

Vats, V., Yadav, S.P. and Grover, J.K. (2003) : Effect of feeding Murraya koeingii and Brassica juncea diet on [correction] kidney functions and glucose levels in streptozotocin diabetic mice. J. of Ethnopharmacol., 85 (1) : 1-5.

Velasquez, M.T., Abraham, A.A., Kimmel, P.L., Farkas, T., Zallasi S. and Michaelis, O.E. (1995) : Diabetic glomerulopathy in the Shrin. Corpulent rat Diabetologia, $38: 31$ 38.

Wang, Y., Zhang, J., Huang, Y. and Hou, T.
(2006) : Hypoglycaemic effect of Artemisia sphaerocephala Krasch seed polysaccharide in alloxaninduced diabetic rats. J. of Swiss Med. Wkly., 136 (33-34): 529-532.

Weichselbaum, T.E. (1946) : An accurate and rapid method for determination of proteins in small amounts of blood serum and plasma. Am. J. Clin. Path., $16: 40$.

WHO (1980) : Expert committee on Diabetes Mellitus, second report. Technical report series 646 World Health organization, Geneva.

Watson(2012): Impact of Mulberry Leaf on Type 2 Diabetes: A review of herbal immunomodulators. J. of Altern. Med. Rev., 11 (2) : 128-150.

Winlers, N., Spelman, K., Burns, J., Nichols, D., Ottersberg, S. and Tenborg, M. (2006): Modulation of cytokine expression by traditional medicines: A review of herbal immunomodulators. J. of Altern. Med. Rev., 11 (2) : 128-150.

Woldehiwet, Z. and Rowan, T.G. (1990) : Some observations on the effects of age of calves on the phagocytosis and killing of Staphylococcus aureus by polymorphonuclear leucocytes. Br. Vet. J. $146: 165$.

Yoon, H. and Liu, R.H. (2007) : Effect of selected phytochemicals and apple extracts on NF-kappaB activation in human breast cancer MCF-7 Cells. J. of Agric. Food Chem., 83 (5) : 211215.

Yound, D.S. (1975) : Determination of GoT. Clin. Chem., $21: 1$.

\section{How to cite this article:}

Magbolah, S.H. Al-Zahrany. 2016. The Use of Some Traditional Herbs to Activating the Immunity of Diabetic Rats. Int.J.Curr.Microbiol.App.Sci. 5(6): 856-874.

doi: http://dx.doi.org/10.20546/ijcmas.2016.506.093 